\title{
STRUKTURALNOŚĆ A DEDUKCYJNOŚĆ MATEMATYKI: WSPÓŁCZESNY STRUKTURALIZM W FILOZOFII MATEMATYKI
}

\begin{abstract}
WSTĘP
Współcześnie strukturalizm matematyczny jest jednym z częściej dyskutowanych stanowisk $\mathrm{w}$ obrębie filozofii matematyki. Jego główną tezą jest stwierdzenie, że przedmiotem zainteresowania matematyki są struktury, a nie pojedyncze obiekty. Literatura przedmiotu tego niejednolitego stanowiska filozoficznego inspiruje do przemyśleń, które można streścić w dwóch pytaniach:

1. Co głoszą przedstawiciele strukturalizmu matematycznego? Jak należy rozumieć stwierdzenie, że matematyka jest nauka o strukturach?

2. Czy matematyka rzeczywiście jest nauką o strukturach? Jeżeli tak, to które ze struktur matematycznych istnieją i w jaki sposób? Jak możemy poznać te struktury?

Celem, który stawiamy przed tym tekstem, jest próba udzielenia odpowiedzi na pierwsze z tych pytań. Chcemy zrozumieć poglądy strukturalistów matematycznych oraz wskazać pewne kluczowe twierdzenia dla tego zróżnicowanego stanowiska filozoficznego. Drugie pytanie traktujemy jako ważne i godne uwagi, ale, poza drobnymi uwagami, nie podejmujemy nawet próby udzielenia na nie odpowiedzi.

To, co wydaje się wspólne dla wszystkich typów strukturalistycznego spojrzenia na matematykę, to zgoda na fakt, że matematyka posiada dwie zasadnicze cechy:
\end{abstract}

Dr Marcin CzAKon - Katolicki Uniwersytet Lubelski Jana Pawła II, Wydział Filozofii, Instytut Filozofii, Katedra Logiki; adres do korespondencji: Al. Racławickie 14, 20-950 Lublin; e-mail: marcin.czakon@kul.pl; ORCID: https://orcid.org/0000-0001-6217-6640. 
( $\alpha$ ) matematyka jest nauka o strukturach;

( $\beta$ ) matematyka jest nauka dedukcyjna.

Wśród autorów piszących prace poglądowe, wprowadzające w zagadnienie strukturalizmu, można znaleźć takie wypowiedzi:

Matematyka wydaje się zajmować, za pomocą mniej lub bardziej rygorystycznych narzędzi dedukcyjnych, badaniem „abstrakcyjnych struktur”, systemów obiektów, spełniających pewne strukturalne relacje między sobą oraz między innymi systemami, bez zwracania uwagi na wewnętrzną naturę obiektów samych w sobie. (Hellman 2005, 536)

Matematyka bada struktury, konstytuowane przez formalne relacje łączące pewne obiekty, abstrahując całkowicie od ewentualnych innych cech tych obiektów. Jednocześnie, co przyjmowane jest jako oczywiste, matematyka jest nauką dedukcyjną, czyli wykorzystuje pewne narzędzia logiczne, za których pomocą uzasadnia swoje twierdzenia. Takie postrzeganie matematyki, jako cechującej się zasadniczo tymi dwiema własnościami, obecne jest również $\mathrm{u}$ autorów traktujących matematykę jedynie jako narzędzie dla innych nauk. Roberto Torretti, filozof fizyki, pisze:

[...] wydaje się, że powinniśmy zwrócić uwagę na dwie zasadnicze cechy: (1) Badania matematyczne polegają na wyprowadzaniu konsekwencji z wyraźnie przyjmowanych założeń, wyprowadzone twierdzenia opisują tę rzeczywistość, która spełnia przyjmowane założenia. Zadaniem matematyki jest stworzenie formalnej teorii i analiza zawartych w niej pojęć, a nie poszukiwanie rzeczywistych przykładów badanej teorii. (2) Matematyka konstruuje i bada pojęcia, które można stosować do jakichkolwiek kolekcji obiektów (wewnętrzna natura tych obiektów nie ma znaczenia), połączonych między sobą relacjami odpowiednimi dla przyjmowanych założeń. Praca matematyka nie polega na skupianiu uwagi na obiektach samych w sobie, ale jedynie na systemie relacji między nimi. Innymi słowy, matematyka jest nauką o strukturach i o typach struktur. (TORRETTI 1999, 4)

Rozumienie zatem matematyki jako nauki o strukturach sprowadza się do stwierdzenia, że kluczowa dla tej nauki jest koniunkcja dwóch własności: $(\alpha)$ matematyka jest nauka o strukturach oraz ( $\beta$ ) matematyka jest nauka dedukcyjna. Różni autorzy, zwolennicy różnych typów strukturalizmu matematycznego, są zgodni co do takiego rozumienia matematyki. Odmienne typy strukturalizmu matematycznego powstają nie poprzez zanegowanie którejś z tych własności lub związku koniunkcji między nimi, ale na skutek odmiennego rozumienia tego, czym jest struktura (jakie ma własności i naturę metafizyczną) oraz, ewentualnie, co to znaczy, że jakaś nauka jest nauką dedukcyjną. 
W literaturze można znaleźć różne typologie strukturalizmów matematycznych (Hellman 2001 i 2005; Horsten 2007), Spośród możliwych ujęć dwie strukturalistyczne interpretacje matematyki wysuwają się na pierwszy plan.

$\mathrm{Z}$ jednej strony problem wieloredukcji (BENACERRAF 1965) stanowi inspirację dla strukturalizmu sui generis, który zagadnienie istnienia struktur matematycznych traktuje podobnie do filozoficznego problemu istnienia przedmiotów ogólnych. Głównymi przedstawicielami tego rodzaju strukturalizmu są Stewart Shapiro (strukturalizm ante rem) oraz Michael Resnik (strukturalizm in re). Strukturalizm sui generis jest dzisiaj wciąż żywo dyskutowany i większość publikacji w ogóle dotyczących omawianej tematyki odnosi się właśnie do tak rozumianego strukturalizmu matematycznego.

Z drugiej strony historyczna idea uniknięcia antynomii oraz wskazania ostatecznej podstawy dla całej matematyki, która doprowadziła do powstania i rozwoju teorii mnogości, jest inspiracją dla innego typu strukturalizmu. W tym ujęciu cała klasyczna matematyka traktowana jest jako pewna sformalizowana teoria aksjomatyczna. To ujęcie nazywane jest w literaturze strukturalizmem teoriomnogościowym, często jako jego inspiratorów podaje się twórców teorii mnogości, a poglądy Richarda Dedekinda przez niektórych są interpretowane jako wprost strukturalistyczne (Hellman 1989; SHAPIRO 1997; RECK 2003).

Celem tego artykułu jest przedstawienie pewnej możliwej interpretacji matematyki jako nauki o strukturach. Zasadniczą cechą prezentowanego stanowiska będzie inne spojrzenie na wspomniane już dwie cechy matematyki, jej $(\alpha)$ strukturalność oraz $(\beta)$ dedukcyjność. Dyskutowane w literaturze typy strukturalizmu traktują te dwie cechy jako różne i jednocześnie przysługujące matematyce, pokażemy, że pod pewnymi warunkami możliwe jest traktowanie tych cech jako równoważnych. Ten pogląd może być postrzegany jako próba pewnego rodzaju unifikacji - wskazania tego, co wspólne dla strukturalizmów różnego typu. Dlatego też niniejszy artykuł może być uważany za próbę odpowiedzi na pierwsze z postawionych na początku pytań. Spróbujemy zrozumieć, co dokładnie twierdzą zwolennicy strukturalizmu jako stanowiska w obrębie filozofii matematyki. Przypuszczamy, że pod pewnymi warunkami będzie można uznać, iż zachodzi następująca równoważność: $(\alpha)$ matematyka jest nauka o strukturach wtedy i tylko wtedy, gdy ( $\beta$ ) matematyka jest nauka dedukcyjnq. Chcemy zastrzec we wstępie, że argumentujemy za tym, jak można rozumieć stanowisko strukturalistyczne, a nie za tym, że matematyka jest nauką o strukturach lub nie jest. Sprawę natury obiektów matematycznych i ewentualnego statusu matematyki jako nauki uważamy za dyskusyjną i pozostawiamy otwartą. 
Jednym z najbardziej wpływowych typów strukturalizmu we współczesnej filozofii matematyki jest strukturalizm sui generis, który traktuje struktury jako obiekty same w sobie — w podobny sposób, jak są traktowane pojęcia ogólne w filozoficznym sporze o uniwersalia. Ten typ strukturalizmu w dojrzałej formie pojawił się pod koniec XX wieku, chociaż jako pracę pionierską traktuje się próbę rozwiązanie problemu wieloredukcji przez Pula Benacerrafa (1965). Różne rodzaje tego typu strukturalizmu powstają na skutek zajęcia przez ich twórców określonego stanowiska metafizycznego odnośnie do sposobu istnienia i poznania struktur jako takich,

Do grona głównych przedstawicieli tego nurtu należy Michael Resnik (strukturalizm in re), który zamiast o strukturze mówi o wzorcu (pattern) (RESNIK 1997). Jego poglądy filozoficzne odnośnie do sposobu istnienia wzorców (struktur) porównuje się do arystotelesowskiego stanowiska umiarkowanego realizmu pojęciowego $\mathrm{w}$ sporze o uniwersalia. Według niego wzorce istnieją tylko dlatego, że możemy znaleźć jakieś ich przykłady.

Najbardziej wpływowym przedstawicielem strukturalizmu jest Stewart Shapiro (strukturalizm ante rem), który struktury matematyczne rozumie jako abstrakcyjne, niezależne, idealne byty, podobne do platońskich idei (SHAPIRO 1997). Struktury matematyczne według niego istnieją niezależnie od jakichkolwiek swoich przykładów.

Wspólne dla różnych odmian strukturalizmu sui generis jest to, że struktury — dowolnie postrzegane: jako wzorce Resnika lub struktury niezależne Shapiro - traktuje się jako pewne abstrakcyjne byty, które konstytuowane są dzięki formalnym relacjom, zachodzącym pomiędzy miejscami danej struktury. Strukturalne relacje, o których mowa, wyznaczają wszystkie własności badanej struktury w taki sposób, że obiekty, zajmujące miejsca w tej strukturze, są całkowicie dowolne i traktowane, jakby nie posiadały żadnych innych cech jak właśnie tylko te relacyjne, które je łączą.

Resnik posługuje się pojęciem wzorca, przez które rozumie pewną strukturę. Wzorzec jest to byt

zawierający jeden lub więcej obiektów, które nazywam pozycjami pozostającymi w różnych relacjach [...] Pozycja jest podobna do punktu w geometrii. Nie ma on innych cech niż te, które posiada na mocy bycia określoną pozycją we wzorcu, do którego przynależy. (RESNIK 1997, 202-203)

Struktura to pewne obiekty, zajmujące konkretne pozycje, pozycje te wyznaczone są przez relacje danej struktury. Obiekty w strukturze albo nie 
posiadają żadnych cech innych niż relacyjne, albo, jeżeli je posiadają, to nie mają one żadnego znaczenia przy badaniach matematycznych. Mówi się, że matematyka abstrahuje od ewentualnych cech innych niż relacyjne.

Te obiekty matematyczne, którymi są byty oznaczane przez stałe matematyczne i kwantyfikatory, są punktami bez struktury lub miejscami w strukturach. Nie posiadają one, tak jak miejsca w strukturze, ani identyczności, ani własności poza strukturą. (RESNIK 1981, 530)

Resnik uważa pojęcie punktu geometrycznego jako właściwie obrazujące sposób rozumienia tego, jak matematyka traktuje wszystkie obiekty matematyczne, zajmujące miejsca danej struktury. Wszystkie cechy punktu geometrycznego, które interesują matematykę, można opisać za pomocą pewnych relacji, które tworzy on z innymi punktami.

[O]biekty matematyczne nie mają wyróżniających ich cech z wyjątkiem tych, które mają na mocy ich relacji do innych pozycji w strukturze, do której należą. Najkrócej mówiąc, uważam punkty geometryczne [...] za paradygmatyczny obiekt matematyczny. (RESNIK 1996, 84)

Definicję struktury, wypowiedzianą wprost, można znaleźć w pracach Shapiro, którego koncepcja strukturalizmu stanowi zasadniczy punkt odniesienia dla współczesnych rozważań. Według tego autora „struktura jest to kolekcja miejsc oraz skończonej liczby [...] relacji na tych miejscach " (SHAPIRO 1997, 93). Struktura przeciwstawiona jest systemowi, czyli „kolekcji miejsc z jednej lub wielu struktur wraz z pewnymi relacjami [...] dla tych miejsc" (ShaPIRo 1997, 93). System jest pewnym konkretnym przykładem struktury, natomiast struktura traktowana jest jako pewna abstrakcyjna forma systemu, którą konstytuują relacje. Systemem jest ciąg liczb porządkowych, który przez Johanna von Neumanna jest identyfikowany ze strukturą liczb naturalnych, taki, że: $0=\emptyset, 1=\{\emptyset\} 2=\{\emptyset,\{\emptyset\}\}, 3=\{\emptyset,\{\emptyset\},\{\emptyset,\{\emptyset\}\}\}$ itd. (von Neumann, 1923). Systemem jest również ciąg zbiorów Ernsta Zermelo, spełniający aksjomaty arytmetyki liczb naturalnych, taki, że: $0=\emptyset, 1=\{\emptyset\}$, $2=\{\{\emptyset\}\} 3=\{\{\{\varnothing\}\}\}$ itd. (Zermelo 1908). Natomiast przez strukturę liczb naturalnych, czyli abstrakcyjną formę systemu liczb naturalnych, rozumie się kolekcję dowolnych obiektów wyznaczoną przez element początkowy i funkcję następnika. Według Shapiro struktury matematyczne, a więc relacje je konstytuujące, są niezależne (SHAPIRo 1997, 100). 
Niezależna jest każda struktura, która spełnia dwa warunki:

a) tworzą ją tylko relacje pomiędzy jej miejscami (To, czy i jakie obiekty zajmują miejsca danej struktury oraz czy te obiekty posiadają jakieś inne cechy niż relacyjne, nie ma żadnego znaczenia).

b) relacje, które ją tworzą są relacjami formalnymi.

Niezależne są zatem te struktury, które składają się z formalnych relacji. Nic ponad to strukturalizm sui generis nie zakłada na temat struktur matematycznych.

Niezależność struktur matematycznych zostaje wyjaśniona, dzięki analizie proponowanego rozróżnienia dwóch perspektyw badawczych (SHAPIRO 1997, 10). Z jednej strony, struktury można badać z perspektywy miejscjako-urzędów (places-are-offices). W ten sposób traktuje się pozycje w strukturze, mówiąc o jednym lub wielu przykładach danej struktury. Biorąc strukturę władzy danego uniwersytetu, możemy rozważyć konkretny jej przykład, czyli aktualne lub historyczne kolegium rektorskie oraz senat. W tej perspektywie możemy powiedzieć, że osoby zajmujące konkretne urzędy, posiadają różne niestrukturalne cechy (np.: „Obecny rektor posiada wybitne cechy przywódcze"). Badanie struktur z tej perspektywy pokazuje, że miejsca (urzędy) w danej strukturze mogą zajmować różne obiekty, posiadające różne, niestrukturalne cechy. Z drugiej strony, struktury można badać z perspektywy miejsc-jako-obiektów (places-are-objects). W ten sposób patrzymy na struktury, jeżeli chcemy powiedzieć, że dane miejsce (pozycja) w strukturze posiada pewne cechy relacyjne. Na przykład powiemy, że przełożonym wszystkich prorektorów jest rektor, albo że nadzór nad pracą rektora sprawuje Wielki Kanclerz. W tej perspektywie zwracamy uwagę tylko na relacje, jakie zachodzą między miejscami badanej struktury, jednocześnie abstrahując od innych cech obiektów zajmujących te miejsca. Miejsce staje się obiektem samym w sobie ze względu na relacje w strukturze, które mu przysługują. Nie jest ważne co lub kto zajmuje to miejsce, ważne są jedynie relacje między miejscami struktury. Pierwszy zatem warunek niezależności struktur matematycznych, o którym mówi Shapiro, objawia się właśnie w tym, że matematyka traktuje wszystkie struktury $\mathrm{z}$ perspektywy miejsc-jakoobiektów. Według strukturalistów typu sui generis dla matematyki nie ma żadnego znaczenia, jakie przedmioty (byty) zajmują miejsca danej struktury, ważne są tylko relacje, które zachodzą między tymi miejscami. Relacje zachodzące między dowolnymi obiektami, konstytuują niezależne struktury matematyczne. 
Drugim warunkiem niezależności struktur matematycznych jest stwierdzenie, że relacje konstytuujące strukturę są relacjami formalnymi.

W strukturach matematycznych wszystkie relacje są formalne lub strukturalne. Na przykład jedynymi warunkami nakładanymi na relację następnika są te, żeby była to funkcja różnowartościowa, gdzie zero nie znajduje się w zbiorze jej wartości, oraz żeby spełniała zasadę indukcji. Żadne czasoprzestrzenne, umysłowe, osobiste lub duchowe własności funkcji następnika nie są ważne dlatego, żeby była ona omawianą funkcją. (SHAPIRo 1997, 98)

Według Shapiro „każda relacja pewnej struktury, która może być całkowicie zdefiniowana tylko przy użyciu języka logiki oraz innych obiektów i relacji danego systemu", jest relacją formalną. Nieprecyzyjnie mówiąc: „, formalny język chwyta formalne relacje" (SHAPIRO 1997, 98).

W kolejnych punktach dokładniej przeanalizujemy omówione rozumienie struktur matematycznych tak pojmowanych. Obecnie wystarczy zauważyć, że poglądy strukturalistów sui generis pokrywają się z proponowanym we wstępie opisem matematyki jako $(\alpha)$ nauki o strukturach i $(\beta)$ nauki dedukcyjnej. Struktury traktowane są jako pewne niezależne byty, wyznaczane tylko przez formalne relacje między dowolnymi obiektami, a nawet pewnymi pustymi miejscami, które mogą być zajętej przez dowolne obiekty, Dedukcyjność matematyki zakładana jest najczęściej implicite.

\section{STRUKTURALIZM TEORIOMNOGOŚCIOWY}

We współczesnych dyskusjach dotyczących filozofii matematyki pojawia się również, jako pewien wariant strukturalizmu matematycznego, stanowisko nazywane strukturalizmem teoriomnogościowym. Jego zwolennicy twierdzą, że bazową i najbardziej fundamentalną teorią dla całej matematyki jest teoria mnogości. Do tej teorii sprowadzane są wszystkie działy matematyki klasycznej i w tej teorii ostatecznie szuka się odpowiedzi na pytanie, czym są i jaką mają naturę obiekty matematyczne.

Jak wiadomo, historia teorii mnogości jako nauki świadomie uprawianej rozpoczyna się w XIX wieku badaniami prowadzonymi przez Georga Cantora oraz Richarda Dedekinda. Ich celem jest ugruntowanie podstaw matematyki i znalezienie ostatecznej, oczywistej i niepodważalnej podstawy dla arytmetyki liczb naturalnych. Badania tamtego okresu skupiają się na dwóch pojęciach: (1) pojęciu zbioru oraz (2) pojęciu relacji należenia elementu 
do zbioru (współcześnie oznaczanej przez „є”), które w tamtym okresie traktowane są jako oczywiście zrozumiałe i nie wymagające wyjaśnienia. W pracy Dedekinda z 1888 r. (DEDEKIND 1888) struktura liczb naturalnych identyfikowana jest z systemem prosto nieskończonym, czyli taką strukturą, która wyznaczona jest przez dowolny zbiór i przekształcenie, które z dzisiejszej perspektywy możemy nazwać relacją następnika. Można powiedzieć, że koncepcja Dedekinda była pionierską próbą wyjaśnienia natury liczb naturalnych, $\mathrm{z}$ tego powodu, powszechnie dzisiaj znana aksjomatyzacja arytmetyki zaproponowana przez Giuseppe Peano, przez niektórych nazywana jest aksjomatyzacją Dedekinda-Peano (DADACZYŃski 2002a, 228). W tamtych czasach strukturalna wizja matematyki nie była tak wyraźnie formułowana jak jest to dzisiaj. Współcześnie poglądy Dedekinda są interpretowane jako pionierskie i oryginalne podejście do matematyki jako nauki o strukturach (Hellman 1989; Shapiro 1997; ReCK 2003).

Gottlob Frege, inspirowany pracami twórców teorii mnogości, w projektowanym na trzy tomy dziele Grundgesetze der Arithmetik zaproponował sprowadzenie całej arytmetyki liczb naturalnych do pojęć teorii zbiorów, a tym samym zrekonstruowanie całej klasycznej matematyki w tej teorii. Pojęcia zbioru oraz należenia elementu do zbioru traktowane są przez niego jako oczywiste i niewymagające definicji. Możemy powiedzieć, że to właśnie na tych pojęciach (a właściwie na ich odpowiednikach) miała być zrekonstruowana matematyka z pojęciem liczby jako klasy abstrakcji wszystkich zbiorów równolicznych. Z pracami Fregego, dzięki inspiracji Peano, zapoznał się Bertrand Russell. Po przeanalizowaniu początkowych fragmentów pierwszego tomu jego pracy zauważył, że na gruncie oczywistych i rzekomo niepodważalnych założeń związanych z pojęciem zbioru możliwy jest dowód dwóch zdań sprzecznych. Ten dowód nosi dzisiaj nazwę antynomii Russella.

Ówcześni badacze bardzo szybko znaleźli przyczynę powstawania tej antynomii. Teoria mnogości, w początkowym stadium swojego rozwoju, opierała się na pewnym oczywistym i powszechnie przyjmowanym założeniu odnośnie do zbioru.

Pod pojęciem [...] „zbioru” rozumiem mianowicie ogólnie każdą wielość, która może być pomyślana jako jedność, tj. każdy ogół określonych elementów, które na mocy pewnego prawa mogą być złączone w jedną całość. (CANTor 1883; thumaczenie za: Murawski 1994, 157)

Okazało się, że za możliwością dowodu sprzeczności stoi właśnie to, wydawałoby się oczywiste i niepodważalne, założenie. We współczesnej teorii 
mnogości nosi ono nazwę aksjomatu komprehensji i można je zapisać w następujący sposób:

$$
\exists_{A}: \forall_{x}:(x \in A \equiv P(x))
$$

Aksjomat ten głosi, że dla każdego wyrażenia typu $P(x)$ istnieje zbiór $A$, którego elementami są te i tylko te przedmioty, które spełniają to wyrażenie. Jak widać, założenie to wydaje się oczywiste i naturalne, zapewne dlatego nie budziło większych podejrzeń u twórców teorii zbiorów. Na jego podstawie możliwe są dowody wielu innych, dobrze dzisiaj znanych antynomii. Na przestrzeni lat zaproponowano wiele alternatywnych rozwiązań, które pozwalają uniknąć antynomii. Chęć uniknięcia sprzeczności w podstawach matematyki wymagała rezygnacji z posługiwania się oczywistym i wydawałoby się zastanym pojęciem zbioru. Od tej pory badacze musieli decydować, które zbiory istnieją, a które nie lub wyraźnie powiedzieć, co jest zbiorem i jakie obiekty są jego elementami. Ogólność i uniwersalność przyjmowanych założeń dotyczących zbioru została ograniczona.

Jednym ze sposobów uniknięcia antynomii teoriomnogościowych była próba wyraźnego wskazania wszystkich założeń, które leżą u podstaw teorii zbiorów. Propozycję takiej teorii aksjomatycznej przedstawił Ernst Zermelo (1908), który zamiast aksjomatu (1) przyjął zestaw kilku wyrażeń, wyraźnie stwierdzając, które zbiory istnieją. Uzasadnieniem dla przyjęcia konkretnego zestawu twierdzeń jako podstawowych założeń dla proponowanej teorii była chęć uniknięcia sprzeczności przy jednoczesnym zachowaniu ogólności i oczywistości całej teorii. W teorii Zermelo zamiast antynomii otrzymujemy dowód nieistnienia pewnych zbiorów. Otwartość zbioru założeń z pierwszego etapu rozwoju teorii mnogości w propozycji Zermelo zostaje zastąpiona ustalonym ostatecznie zbiorem aksjomatów, z których na drodze dedukcji wyprowadzane są wszystkie interesujące własności zbiorów, a tym samym cała arytmetyka liczb naturalnych. Oczywistość i ogólność przyjmowanych założeń są bardzo ważne i to one stanowią o tym, które wyrażenia zaliczane są do zbioru aksjomatów. Opisana w tej teorii hierarchia zbiorów rozumiana jest jako pewnego rodzaju struktura, która stanowi bazę dla całej matematyki.

Jak wiadomo, propozycje Zermelo oraz konkurencyjna dla niej w tamtym okresie teoria typów logicznych Bertranda Russella zapoczątkowały nowy okres badań w podstawach matematyki. Od początku XX wieku do dnia dzisiejszego dyskutowane jest wiele różnych, często równoprawnych teorii, 
które aspirują do miana najlepszej podstawy dla matematyki klasycznej. Obszerne badania oraz bogactwo wyników doprowadziły do tego, że potoczne, ogólne i wydawałoby się oczywiste znaczenie, które było przypisywane do pojęcia zbioru oraz relacji należenia $\in$, współcześnie straciło wszystkie te cechy. Znane są różne sposoby rozumienia tych pojęć, w szczególności mówi się o zbiorach w sensie dystrybutywnym oraz kolektywnym, a nawet konstruowane są teorie, w których używa się pojęcia zbioru w ogóle nie nadając mu żadnego znaczenia. Teoria mnogości w swoim zamierzeniu konstruowana jako podstawowa teoria dla pojęcia zbioru, dzisiaj okazuje się nie mieć jednego ustalonego modelu.

Tak rozumiana teoria zbiorów stanowi podstawę dla całej klasycznej matematyki, w ten sposób, że można w niej zrekonstruować strukturę liczb naturalnych oraz pozostałe struktury matematyczne nadbudowywane na niej. Struktura, a właściwie cała hierarchia struktur teoriomnogościowych, jest interpretowana $\mathrm{w}$ ten sposób, że ostateczne pytanie o naturę obiektów matematycznych jest stawiane właśnie w teorii zbiorów. Nie jest to teoria pewnych zbiorów, ale dedukcyjna teoria, która dopiero ustala znaczenie użytych w niej terminów, takich jak zbiór. Strukturalizm teoriomnogościowy traktuje obiekty matematyczne jako pewne dedukcyjne struktury, na których podstawie są budowane inne struktury w ten sposób, że w żadnym wypadku nie mówi się o konkretnych obiektach, a zawsze jest mowa tylko o pewnych formalnych relacjach, które zachodzą między dowolnymi obiektami. Owe relacje są opisywane przez aksjomaty teorii dedukcyjnych, które ustalają znaczenie użytych w nich terminów pierwotnych.

Struktury matematyczne są pewnymi zbiorami, uporządkowanymi ciągami, które składają się ze zbioru, stanowiącego dziedzinę, oraz relacji, funkcji i ewentualnie pewnych wyróżnionych obiektów (należących do dziedziny). Struktury mogą być modelami, spełniającymi twierdzenia pewnych teorii. (HeLLMAN 2005, 538-539)

Strukturalizm teoriomnogościowy stwierdza, że przedmiotem badań matematyki są struktury, które są rozumiane jako układy zbiorów i relacji, natomiast wszystkie twierdzenia pochodne są logicznymi konsekwencjami tak przyjmowanych założeń. Strukturalizm tego typu również potwierdza, że matematyka łącznie posiada dwie cechy $(\alpha)$ strukturalność oraz $(\beta)$ dedukcyjność. 


\section{METODOLOGIA NAUK FORMALNYCH}

Próba rozumienia różnych typów strukturalizmu matematycznego doprowadziła nas do konstatacji, że wspólną ich cechą jest uznanie matematyki jako jednocześnie charakteryzującej się $(\alpha)$ strukturalnością oraz $(\beta)$ dedukcyjnością. Te uwagi pozwalają nam obecnie zadać pytanie, co to znaczy, że pewna nauka jest nauką dedukcyjną (formalną).

Ciekawe i oryginalne podejście do metodologii nauk dedukcyjnych zaproponował Kazimierz Ajdukiewicz. W Logice pragmatycznej (AJDUKIEWICZ 1965) do nauk formalnych zalicza, obok matematyki, również logikę. Według niego każda $\mathrm{z}$ tych nauk przechodzi przez trzy stadia rozwoju, których zasadniczym wyróżnikiem są dopuszczane sposoby uzasadniania twierdzeń oraz przyjmowane znaczenie terminów pierwotnych.

W koncepcji Ajdukiewicza nauki dedukcyjne przeciwstawione są naukom indukcyjnym. Według niego oczywisty jest fakt, że we wszystkich naukach uznaje się pewne zdania jako twierdzenia pierwotne. Zdania te mają tę zasadniczą cechę, że nie są wyprowadzana z innych wcześniej uznanych zdań. To właśnie twierdzenia pierwotne są tymi zdaniami, które służą jako uzasadnienie dla twierdzeń pochodnych danej nauki. Taka konstrukcja, według Ajdukiewicza, jest wspólna dla wszystkich nauk, zarówno dedukcyjnych, jak i indukcyjnych. Podział na nauki dedukcyjne oraz indukcyjne dokonuje się ze względu na dopuszczane w danej nauce sposoby wnioskowania. W naukach dedukcyjnych twierdzenia pochodne można uzasadniać tylko za pomocą dedukcji. Natomiast nauki indukcyjne poza dedukcją korzystają również z innych sposobów wnioskowania, np. z redukcji, indukcji enumeracyjnej lub wnioskowań przez analogię. Do nauk indukcyjnych zalicza się nauki przyrodnicze oraz humanistyczne (AJDUKIEWICz 1965, 178).

Nauki dedukcyjne przechodzą przez trzy stadia (etapy) rozwoju. Pierwsze $\mathrm{z}$ nich nazywany jest stadium przedaksjomatycznym intuicyjnym i posiada trzy zasadnicze cechy:

a) Jako twierdzenia pierwotnie wolno przyjmować dowolne zdania, które badaczowi wydają się oczywiste i które nie spotykają się ze sprzeciwem ze strony innych specjalistów w danej dziedzinie;

b) Jako twierdzenia pochodne wolno przyjmować te zdania, które w oczywisty sposób wynikają ze zdań wcześniej uznanych;

c) Do słownika danej teorii należą te terminy, które dla danego badacza są zrozumiałe bez definicji lub takie, które za pomocą definicji można sprowadzić do tych pierwszych. 
W pierwszym etapie rozwoju nauk dedukcyjnych lista twierdzeń pierwotnych oraz terminów pierwotnych nigdy nie jest ostatecznie zamknięta. W dowolnym momencie można dodać jakieś zdanie, które uznajemy za oczywiste, lub pewien termin, którego znaczenie nie budzi wątpliwości. Stadium zatem przedaksjomatyczne intuicyjne cechuje się otwartościq zbioru twierdzeń pierwotnych oraz słownika, a także oczywistościa przyjmowanych twierdzeń i terminów (AJdukiewicz 1965, 181),

W owym przedaksjomatycznym, nazwijmy je pierwotnym, stadium występuje nauka dedukcyjna jako system twierdzeń stosunkami logicznymi, a nade wszystko stosunkami wynikania powiązanych, z których każdemu przypisuje się prawdziwość opartą na wynikaniu z innego prawdziwego twierdzenia, zaś jako założenia występują sądy, którym przysługuje jakaś oczywistość. Sądy te nie są ani wyraźnie wymienione, ani też nie występują koniecznie jako założenia ostateczne; czasami bowiem występują one jako twierdzenia. W owym pierwotnym stadium wystarczy, jeżeli każdy w nauce występujący sąd jest bądź oczywisty, bądź też oczywistymi związkami wynikania powiązany z sądami oczywistymi. Każde pojęcie jest intuicyjnie dane, wyraz, który je oznacza, bez bliższych wyjaśnień zrozumiały lub też przez szereg definicyj sprowadzony do wyrazów zrozumiałych bezpośrednio, o których się zwykło mówić, że ich już wyjaśniać nie trzeba. Poza tym owe już nie wymagające określenia wyrazy i te nie wymagające analizy pojęcia nie są wyraźnie wymienione i też niekoniecznie zawsze jako takie występują. (AJdUKIEwICZ 1921, 1)

Przejście na drugi etap rozwoju nauk formalnych, nazywany aksjomatycznym intuicyjnym, dokonuje się poprzez ostateczne ustalenie i zamknięcie zbioru twierdzeń pierwotnych oraz słownika terminów pierwotnych. Natomiast nadal oczywistość pozostaje tym kryterium, które uzasadnia przyjęcie tych a nie innych twierdzeń i terminów. Drugie stadium rozwoju nauk dedukcyjnych posiada zatem następujące cechy:

a) Nadal jako twierdzenia pierwotnie wolno przyjmować dowolne zdania, które badaczowi wydają się oczywiste i które nie spotykają się ze sprzeciwem ze strony innych specjalistów, ale należy ustalić i ostatecznie zamknąć zbiór tych twierdzeń,

b) Jako twierdzenia pochodne wolno przyjmować tylko te zdania, które wynikają dedukcyjnie z przyjętego zbioru twierdzeń pierwotnych.

c) Nadal do słownika danej teorii należą te terminy, które dla danego badacza są zrozumiałe bez definicji lub takie, które za pomocą definicji można sprowadzić do tych pierwszych, ale należy ustalić i ostatecznie zamknąć zbiór terminów pierwotnych. 
Znika otwartość zbioru twierdzeń pierwotnych oraz słownika terminów pierwotnych, która cechowała pierwszy przedaksjomatyczny intuicyjny etap, w jej miejsce pojawiają się ostatecznie ustalone i zamknięte zbiory twierdzeń i terminów pierwotnych. Oczywistość twierdzeń nadal pozostaje tym kryterium, które decyduje o ich przyjęciu, W związku z tym jedynym akceptowanym sposobem uzasadniania twierdzeń pochodnych jest dedukcja. Przyjęty raz na zawsze zbiór twierdzeń pierwotnych staje się podstawą całej teorii i jedynie $\mathrm{z}$ niego, na zasadzie dedukcji, można wyprowadzać inne twierdzenia danej teorii.

Przejście w stadium aksjomatyczne polega na tym, że lista twierdzeń pierwotnych, tj. takich, które przyjmujemy nie dowodząc ich już w obrębie danej nauki, jak również lista terminów pierwotnych, tj. takich, którymi wolno nam się posługiwać bez podawania ich definicji, zostaje w pewnej fazie rozwoju tej nauki zamknięta.

Po przejściu w stadium aksjomatyczne nie wolno już przyjmować każdego zdania oczywistego bez dowodu i nie wolno bez definicji posługiwać się dowolnym terminem powszechnie zrozumiałym, lecz wolno to czynić tylko, gdy zdanie to, czy ów termin, znajduje się na odpowiedniej liście. (AJdukiewicz 1965, 182)

Trzeci, ostatni etap rozwoju nauk dedukcyjnych Ajdukiewicz nazywa stadium aksjomatycznym abstrakcyjnym. Zbiory twierdzeń pierwotnych oraz terminów pierwotnych są już ustalone i zamknięte, a oczywistość jako kryterium dla ich przyjmowania zostaje zastąpiona abstrakcją. W związku $\mathrm{z}$ tym, że abstrahujemy od znaczenia, jakie posiadają terminy pierwotne, nie nakładamy żadnego warunku na przyjmowane twierdzenia pierwotne, można je przyjmować całkowicie dowolnie, bez żadnego uzasadnienia, bez oczywistości, która cechowała poprzednie stadia rozwoju danej nauki. Intuicja, prawdziwość, ewentualne doświadczenie empiryczne lub wewnętrzne nie odgrywają żadnej roli w nauce znajdującej się w trzecim aksjomatycznym abstrakcyjnym stadium. Jedynym narzędziem do uzasadniania twierdzeń jest dedukcja, za jej pomocą $\mathrm{z}$ aksjomatów wyprowadzane są twierdzenia pochodne. Znaczenie użytych $\mathrm{w}$ aksjomatach terminów pierwotnych nie odgrywa żadnej roli (abstrahujemy od niego), nie posiadają one żadnego znaczenia, ewentualnie można powiedzieć, że terminy pierwotne przyjmują to znaczenie, które dane im jest przez użycie ich w aksjomatach.

Stadium intuicyjne nauk dedukcyjnych tym się charakteryzuje, że terminy pierwotne, tj. terminy, których się używa bez podawania ich definicji, bierze się w znaczeniu zastanym i od twierdzeń pierwotnych czy od aksjomatów żąda się, 
aby były przy zastanym znaczeniu zawartych $\mathrm{w}$ nich terminów oczywiste, tj. by były dla każdego przekonywujące bez podawania dowodu. Zasadnicza różnica między intuicyjnym sposobem uprawiania nauk dedukcyjnych a sposobem występującym $w$ stadium abstrakcyjnym polega na tym, że się $\mathrm{w}$ tym drugim stadium abstrahuje od zastanego znaczenia swoistych terminów pierwotnych, że się ich znaczenie dopiero konstytuuje. Zachowując mianowicie znaczenie terminów zapożyczonych z nauk, na których się opieramy, postanawiamy co do terminów swoistych danej nauki, że terminy te mają być nazwami takich tworów, które czynią zadość warunkom, jakie na nie nakładają aksjomaty, nie zważając na to, czego nazwami te terminy były przy ich dotychczasowym (zastanym) znaczeniu i czy w ogóle miały dotychczas jakieś znaczenie. (AJduKIEwICZ 1965, 188)

Rozważmy elementarna teorię mniejszości jako przykład pewnej teorii dedukcyjnej, która znajduje się na trzecim aksjomatycznym abstrakcyjnym etapie rozwoju. Teoria ta jest oparta na logice pierwszego rzędu. Dlatego terminy zaczerpnięte z logiki mają ustalone znaczenia, a do swoistych dla badanej nauki terminów pierwotnych należą:

$<\quad$ odczytujemy: ,jest mniejsze";

$=$ odczytujemy:, jest równe";

$L w$ odczytujemy: ,liczba wymierna”.

Dodatkowo w alfabecie tej teorii znajdują się symbole zmiennych $x, y, z$, których zakresem zmienności jest zbiór liczb wymiernych. Zbiór aksjomatów swoistych dla elementarnej teorii mniejszości zawiera siedem twierdzeń, które wyjaśniają sposób użycia swoistych terminów pierwotnych. Jednym $\mathrm{z}$ tych aksjomatów jest wyrażenie:

$$
\forall_{x}: \exists_{y}:(x<y)
$$

Co można odczytać: dla każdego $x$ istnieje takie $y$, że $x<y$. Przy ustalonym wyżej znaczeniu użytych w tym wyrażeniu terminów, zdanie to można odczytać w ten sposób: dla każdej liczby wymiernej istnieje liczba wymierna od niej większa.

Nic nie stoi na przeszkodzie, żeby to intuicyjne rozumienie swoistych terminów pierwotnych zastąpić innym. Abstrahujemy od zastanego oczywistego znaczenia tych terminów i nadajemy im nowe znaczenie, jednocześnie nie zmieniając nic innego w badanej teorii dedukcyjnej Ajdukiewicz (1965, 190) podaje przykładowe trzy inne rozumienia swoistych terminów pierwotnych. 
Tablica 1: Interpretacja terminów pierwotnych

\begin{tabular}{c|c|c}
$L w$ & $<$ & zakres zmienności zmiennych $x, y, z$ \\
\hline liczba wymierna & większy & liczby wymierne \\
liczba rzeczywista & mniejszy & liczby rzeczywiste \\
punkt na danej prostej & leży na lewo & punkty na danej prostej \\
chwila czasowa czasowa & jest wcześniejsza & chwile czasowe \\
$\ldots$ & $\ldots$ & $\ldots$
\end{tabular}

Zgodnie z tablicą (1) symbol < możemy odczytać na wiele różnych sposobów, a zakres zmienności zmiennych $x, y, z$ może odpowiednio przebiegać różne zbiory indywiduów. Podany aksjomat można odczytać jako opisujący położenie punktów na prostej: dla każdego punktu x na danej prostej istnieje punkt y na tej prostej taki, że x leży na lewo od y. Równie dobrze może on opisywać chwile czasowe: dla każdej chwili czasowej $x$ istnieje chwila y taka, że x jest wcześniejszy od y. Możemy powiedzieć, że dla danego układu aksjomatów istnieje wiele różnych modeli, przez które jest on spełniony. Możemy również tę samą teorię dedukcyjną potraktować jako całkowicie abstrakcyjną, w której swoiste terminy pierwotne nie posiadają żadnego znaczenia. Wszystkie aksjomaty oraz twierdzenia pochodne pozostaną niezmienione, teoria rozumiana jako zbiór konsekwencji zbioru aksjomatów pozostaje nienaruszona, natomiast swoistym terminom pierwotnym tej teorii nie nadaje się żadnego znaczenia,

Ajdukiewicz nie jest odosobniony $w$ swoich poglądach na metodologiczne aspekty nauk formalnych. Alfred Tarski rozwój nauk dedukcyjnych widzi w podobny sposób - jako pewnego rodzaju stopniowe ograniczenie oczywistości przyjmowanych założeń:

Stosunkowo wcześniej jednak zdano sobie sprawę, że kryterium intuicyjnej oczywistości i niezawodności nie jest bynajmniej pewne, nie ma obiektywnego charakteru i często prowadzi do poważnych błędów. Cały dalszy rozwój metody dedukcyjnej można uważać za przejaw tendencji zmierzającej do ograniczenia używalności kryterium odwołującego się do intuicyjnej oczywistości. (TARSKI 1969, 320)

Różnice w poglądach wielu autorów piszących na ten temat okazują się wyraźniejsze w perspektywie zaproponowanego przez Ajdukiewicza trójstopniowego rozwoju nauk formalnych. Chociaż aktualne jest pytanie, na 
którym etapie rozwoju obecnie jest matematyka jako nauka formalna i czy koniecznie musi przejść przez wszystkie te etapy, to dla celów postawiony na początku tego artykułu odpowiedź nie ma większego znaczenia. Natomiast to, co ważne, to fakt, że dyskutowane w tym artykule filozoficzne stanowisko strukturalizmu matematycznego w świetle metodologicznej koncepcji Ajdukiewicza może uzyskać pewną nową interpretację.

\section{DEDUKCYJNOŚĆ VS. STRUKTURALNOŚĆ}

Zarówno zwolennicy strukturalizmu sui generis, jak i strukturaliści teoriomnogościowi utrzymują, że $(\alpha)$ matematyka jest nauka o strukturach oraz ( $\beta$ ) matematyka jest nauka dedukcyjna. Zróżnicowanie tych stanowisk bierze się z odmiennego sposobu odpowiedzi na pytanie dotyczące tego, czym jest struktura. Strukturaliści sui generis, m.in. Stewart Shapiro, twierdzą, że struktury matematyczne są to struktury niezależne, czyli struktury składające się z formalnych relacji, które łączą dowolne obiekty. Natomiast strukturaliści typu teoriomnogościowego za struktury uznają pewne układy zbiorów, a nawet całe ich hierarchie, które są wyznaczane za pomocą pewnych aksjomatów. Jednocześnie każde z tych stanowisk uznaje dedukcję za jedyny sposób uzasadniania twierdzeń pochodnych w swoich teoriach.

Metodologiczna wizja nauk formalnych, w której każda $\mathrm{z}$ takich nauk przechodzi przez trzy etapy rozwoju, pozwala spojrzeć na strukturalność matematyki w inny sposób. Zauważmy, że możliwe jest takie rozumienie strukturalizmu, przy którym matematyka jako nauka o strukturach będzie traktowana jako z nauka formalna, znajdująca się w trzecim aksjomatycznym abstrakcyjnym stadium rozwoju. Przy takim rozumieniu matematyki rozróżnienie dwóch zasadniczych jej cech, czyli $(\alpha)$ strukturalności oraz $(\beta)$ dedukcyjności okaże się zbędne. W tym sensie można powiedzieć, że strukturalność i dedukcyjność są tym samym.

[...] wymieniamy szereg symboli; symbole te wchodzą w skład aksjomatów, na ich zaś podstawie «udowadniamy» szereg «twierdzeń». Symbolom tym nie przypisujemy żadnego znaczenia. Dlaczego je jednak nazywamy symbolami, a nie kreskami lub ornamentami? Wszakże - zdawałoby się — istotą symbolu jest, że symbol coś znaczy. Niewątpliwie symbole pierwotne nauk dedukcyjnych nie są w tym znaczeniu symbolami, jak np. wyrazy mowy potocznej. [...] Mimo to jednak różnią się od zwykłych kresek lub ornamentów [...] Zarówno symbole nauk dedukcyjnych, jak i figury w szachach są o tyle symbolami, o ile występują 
w takich a takich związkach. Związkami tymi dla symboli nauk dedukcyjnych są aksjomaty i twierdzenia. [...] Są tedy symbole nauk dedukcyjnych symbolami nie dlatego, jakoby «coś znaczyły» albo «coś oznaczały», lecz dlatego, że mają określoną «rolę», dlatego, że występują w ściśle określonych związkach. (AJduKIEWICZ 1921, 2-3)

Każda nauka formalna, znajdująca się w stadium aksjomatycznym abstrakcyjnym jest nauką czysto dedukcyjną, czyli jest nauką o pewnych strukturach. Na ostatnim etapie rozwoju nauk formalnych dwie wydawałoby się różne własności wskazują na tę samą cechę. Strukturalność i dedukcyjność zlewają się w jedną własność i nie ma między nimi żadnej różnicy. W związku z tym, jeżeli matematykę traktujemy jako naukę znajdującą się w trzecim aksjomatycznym abstrakcyjnym stadium swojego rozwoju, to możemy powiedzieć, że jest $(\alpha)$ nauka o strukturach wtedy i tylko wtedy, gdy $(\beta)$ jest nauka dedukcyjną.

Zwróćmy uwagę na kilka argumentów za tym, że przedstawione współczesne poglądy strukturalistyczne na matematykę są bliskie tego rodzaju stanowisku. Strukturalizm teoriomnogościowy, który całą matematykę sprowadza do pewnej, wybranej teorii mnogości (np. ZFC, NBG), opiera się na teoriach, które znajdują się $\mathrm{w}$ trzecim aksjomatycznym abstrakcyjnym stadium swojego rozwoju. Badania prowadzone w celu aksjomatyzacji intuicyjnej teorii mnogości pokazują, że bogactwo i różnorodność osiąganych wyników stanowią argument za traktowaniem współczesnej matematyki jako znajdującej się w trzecim aksjomatycznym abstrakcyjnym stadium swojego rozwoju. Aksjomaty dla proponowanych teorii można dobierać zupełnie dowolnie, użyte w nich terminy pierwotne nie posiadają żadnego zastanego znaczenia, jedynym ograniczeniem dla konstruowanych systemów dedukcyjnych jest wymóg, żeby zbiór aksjomatów (reguł, wyrażeń, dowodów) był rozstrzygalny. Ustalenie zbioru aksjomatów jest całkowicie arbitralne, natomiast późniejsza dedukcja na ich podstawie twierdzeń pochodnych odbywa się wedle ściśle określonych prawideł logicznych. Można powiedzieć, że matematyka tak rozumiana jest nauką czysto dedukcyjną, jedynym akceptowalnym sposobem uzasadniania twierdzeń jest dedukcja, żadne inne uzasadnienie nie jest wymagane, co więcej — nie jest akceptowane.

Wszystkie te wyniki pokazują, że teoria mnogości oparta na aksjomatyce Zermelo-Fraenkla jest niezupełna, i to w bardzo silnym stopniu. [...] Niezupełność aksjomatycznej teorii mnogości porównać można raczej do niezupełności teorii grup lub ciał lub podobnych teorii algebraicznych. Nikt nie dziwi się, że te teorie są niezupełne. Ich aksjomatyki były od początku sformułowane tak, by istniały dla 
nich różnorodne modele. $\mathrm{W}$ przypadku aksjomatów teorii mnogości intencja była odmienna, ale wyniki są niemal takie same. (Mostowski 1976, 110)

Strukturalizm zatem teoriomnogościowy, który twierdzi, że $(\alpha)$ matematyka jest nauką o strukturach, struktury rozumie w ten sposób, że konstytuują je dowolne aksjomaty, na podstawie których, za pomocą dedukcji, uzasadniane są pozostałe twierdzenia dotyczące danej struktury, Strukturalność tych konstrukcji wyraża się w tym, że budowa teorii dedukcyjnej rozpoczyna się od pewnych aksjomatów, w których użyte są dane terminy pierwotne, o których znaczeniu zakłada się tylko to, co stwierdzono w aksjomatach. Teorie dedukcyjne tak rozumiane mogą być traktowane jako całkowicie uniwersalne i przygotowane, jako pewne struktury, do dowolnej interpretacji.

Mogłaby się nasunąć myśl, że zamiast przyjmować „0”, „liczbę” i „następnik” jako terminy, których znaczenie znamy, choć ich definiować nie możemy, moglibyśmy przyjąć je jako nazwy jakichś trzech rzeczy, które spełniają pięć aksjomatów Peana. Wówczas nie będą to terminy, które mają znaczenie określone, choć niezdefiniowane - wówczas będą to „zmienne”, to znaczy terminy, co do których robimy pewne założenia, mianowicie te, jakie są sformułowane $\mathrm{w}$ pięciu aksjomatach, lecz które poza tym są niezdeterminowane. Jeżeli przyjmiemy ten sposób rozumienia, to twierdzeń naszych będzie się dowodziło nie w odniesieniu do określonego zbioru rzeczy, zwanych ,liczbami naturalnymi”, lecz w odniesieniu do wszystkich zbiorów rzeczy, które mają pewne własności. (Russell 1920, 27)

Na przykład arytmetykę Peano, opartą na pięciu aksjomatach, można rozumieć w ten sposób, że ten niewątpliwie czysto dedukcyjny system, w którym nie ustala się żadnego znaczenia dla jego terminów pierwotnych, opisuje pewną strukturę. Opis ten jest uniwersalny i otwarty w tym sensie, że terminom pierwotnym można nadać dowolną interpretację, a twierdzenia pochodne tej teorii dotyczą wszystkich zbiorów rzeczy, o których może orzekać ta teoria. Przy takim rozumieniu teorii dedukcyjnych zatarta zostaje granica pomiędzy strukturą jako pewnym obiektem, który podlega badaniu przez matematykę, a opisem tej struktury za pomocą aksjomatów i wykorzystywanych w nich terminów. W trzecim aksjomatycznym abstrakcyjnym stadium struktura jako obiekt oraz opis tej struktury jako pewna teoria dedukcyjna są tożsame. Wróćmy teraz do sposobu rozumienia terminu „struktura" przez zwolenników strukturalizmu sui generis. Twierdzą oni, że w matematyce mowa jest o strukturach niezależnych, które przeciwstawione są innym strukturom i które konstytuowane są dzięki formalnym relacjom 
łączącym dowolne obiekty. Struktury poznajemy dzięki ich opisowi, a najlepszym opisem dla struktury jest podanie pewnych założeń, na których podstawie uzyska się całościowy obraz badanej struktury. W pracy Shapiro (1997, 94-95) zostaje wymienionych kilka aksjomatów, które mają stanowić opis pewnej struktury fundamentalnej dla całej matematyki. Istnieje wyraźna analogia między aksjomatami pewnej teorii mnogości a propozycją aksjomatyzacji teorii struktur.

W jakimś sensie teoria mnogości i prezentowana teoria struktur są swoimi notacyjnymi wariantami. W szczególności teoria struktur bez aksjomatu refleksji odpowiada teorii mnogości drugiego rzędu ZFC, a teoria struktur wraz z aksjomatem refleksji odpowiada teorii mnogości z odpowiednim aksjomatem refleksji. (SHAPIRO 1997, 96)

Traktowanie struktur matematycznych jako pewnych abstrakcyjnych, czysto formalnych zbiorów relacji między dowolnymi obiektami pozwala interpretować stanowisko strukturalistów sui generis jako bardzo podobne do stanowiska strukturalistów teoriomnogościowych. To podobieństwo ujawnia się jeszcze bardziej w momencie analizy pewnych szczegółowych dyskusji. Charles Parsons (1990) w swoim artykule podaje argumenty przeciwko strukturalizmowi, których głównym celem jest wskazanie nierelacyjnych i nieformalnych cech obiektów matematycznych. Istnienie takich cech miałoby być dowodem na to, że matematyka być może nie jest nauką wyłącznie o strukturach niezależnych lub ewentualnie nie tylko struktury leżą w obszarze jej zainteresowań.

Parsons twierdzi, że istnieją różne rodzaje obiektów. Poza obiektami czysto matematycznymi (strukturami) oraz obiektami konkretnymi istnieją również tak zwane obiekty quasi-konkretne. Byty quasi-konkretne posiadają pewne cechy, które nie są własnościami relacyjnymi w rozumieniu formalnym. Jako przykłady takiego rodzaju obiektów Parsons wymienia figury geometryczne, które według niego są koniecznie związane z jakąś fizyczną ich reprezentacją (pewnym przedstawieniem). Podobnie myśli on o ciągach znaków wraz z fizyczną relacją konkatenacji, czyli zestawienia jednego napisu obok drugiego. Istnienie obiektów quasi-konkretnych wraz z pewnymi relacjami nieformalnymi ma być argumentem, który wskazywałby, że matematyka nie jest nauką o strukturach rozumianych w ten sposób, że są one niezależne, czysto formalne. 
Obiekty czysto matematyczne są odmienne nie tylko od obiektów konkretnych, ale również od pewnych abstrakcyjnych obiektów, które ja nazywam quasi-konkretnymi, ponieważ są one w bezpośredni sposób „reprezentowane” lub „odzwierciedlane" w konkretach. [...] Czysto strukturalne podejście nie wydaje się być właściwym dla obiektów quasi-konkretnych, ponieważ relacja reprezentacji jest czymś innym niż wewnątrz-strukturalne relacje. (PARSONs 1990, 304)

Ta i inne próby wskazania pewnych nierelacyjnych (niestrukturalnych) cech obiektów matematycznych spotykają się z repliką ze strony strukturalistów. Strukturaliści twierdzą, że nawet jeżeli obiekty quasi-konkretne istnieją, to są one tylko pewnego rodzaju etapem przejściowym w rozwoju matematyki. Figury geometryczne już w XVII wieku, dzięki odkryciom René Descartes'a oraz Pierre'a de Fermata, przestały być traktowane jako z konieczności uwikłane w jakiegoś rodzaju quasi-fizyczność. Współcześnie zaś geometrii analitycznej, jako pewnemu fragmentowi matematyki klasycznej, wystarczą jedynie metody obliczeniowe (formalne), ponieważ ostatecznie ugruntowana jest ona na pewnej strukturze, którą da się zredukować do liczb naturalnych. Ponadto, dla wielu badaczy, powstanie geometrii nieeuklidesowych stanowi argument za tym, że geometria nie jest w żaden sposób związana z jakimikolwiek intuicyjnymi przedstawieniami i wyobrażeniami. Podobnie należy traktować ciągi napisów wraz z relacją konkatenacji. Przynajmniej od przedstawionej przez Kurta Gödla propozycji jednoznacznego numerowania wyrażeń, możliwa jest całkowita rezygnacja $\mathrm{z}$ operowania na ciągach, powstających przez zestawianie napisów, i posługiwanie się jedynie działaniami na liczbach (ShapIro 1997, 102-107). Dla naszych celów nie jest ważne, która ze stron tego sporu ma rację, czy obiekty matematyczne są obiektami czysto relacyjnymi, czy z konieczności przysługują im jakieś inne cechy. Dla rozważań prowadzonych w tym artykule ważny jest jedynie sposób argumentacji strukturalistów. Strukturaliści sui generis twierdzą, że tym, co bada matematyka, nie są obiekty quasi-konkretne, ale struktury niezależne, czyli obiekty abstrakcyjne. Jeżeli nawet na pewnym etapie swojego rozwoju konkretne działy matematyki posługują się jakiegoś rodzaju wyobrażeniami lub quasi-konkretami, to późniejsza ich ewolucja i dogłębne zbadanie danej dziedziny prowadzi do wyraźnego wskazania abstrakcyjnej, niezależnej struktury, która jest opisana tylko za pomocą formalnych relacji. Strukturą tego rodzaju może być struktura liczb naturalnych, do której można sprowadzić geometrię oraz za jej pomocą, wykorzystując technikę jednoznacznej numeracji wyrażeń, można mówić o dowolnych ciągach znaków. 
Argumentacja prezentowana przez strukturalistów sui generis sprowadza się do stwierdzenia, że struktury są to abstrakcyjne, niezależne byty, które możemy dowolnie konstruować za pomocą ich opisu. Abstrakcyjne struktury matematyczne poznajemy

dzięki bezpośredniemu ich opisowi [...] kompetentny użytkownik języka będzie rozumiał, czym jest opisywana struktura, i będzie potrafił dyskutować na temat tej struktury, niezależnie od jakichkolwiek jej przykładów. (SHAPIRo 1997, 74)

Opis, czyli podanie pewnych zasadniczych warunków, determinuje daną strukturę w ten sposób, że nie mówi się o prawdziwości lub fałszywości tych stwierdzeń. Warunki nakładane na opisywane struktury są całkowicie dowolne i nie ma żadnej konieczności uzasadniania tego opisu. Podanie opisu danej struktury stanowi bazę dla dalszych jej badań. Za pomocą rygorystycznych wymogów logiki wyprowadzamy na zasadzie dedukcji pozostałe twierdzenia dotyczące badanej struktury. Wyraźnie zatem widać, że podejście strukturalistów sui generis może być rozumiane jako bardzo podobne do podejścia strukturalistów teoriomnogościowych. Jedynym akceptowalnym sposobem uzasadniania twierdzeń w każdym z tych strukturalizmów jest dedukcja, a różnica między $(\alpha)$ strukturalnością oraz $(\beta)$ dedukcyjnością matematyki zostaje zatarta.

\section{DEDUKCJA A ISTNIENIE STRUKTUR}

W tak rozumianym strukturalizmie nie ma rozróżnienia między przedmiotem badanym przez teorię a samą teorią. To, czy struktury istnieją realnie, podobnie jak byty platońskie, czy są abstrahowane w jakiś sposób, albo mają jeszcze inny status ontologiczny, nie jest ważne. Innymi słowy, to, czy dla pewnej danej aksjomatycznej teorii dedukcyjnej model będzie istniał czy też nie, nie ma znaczenia. Ta teoria sama $\mathrm{w}$ sobie jest traktowana jako struktura czy przedmiot zainteresowania matematyki. Na przykład aksjomaty arytmetyki Peano opisują pewną strukturę i matematyka może z powodzeniem badać tę strukturę za pomocą narzędzi dedukcyjnych, wykazując wszystkie możliwe konsekwencje tych aksjomatów. W żaden sposób nie ma potrzeby uzasadniać statusu ontologicznego tak istniejącej struktury.

Jeden z najczęściej cytowanych i dyskutowanych przedstawicieli współczesnego strukturalizmu matematycznego w kwestii odróżnienia swojego stanowisko od pewnych klasycznych koncepcji filozoficznych pisze tak: 
$\mathrm{Z}$ tradycyjnego platońskiego punktu widzenia istnieje pewna ważna autonomia między aksjomatami a badanymi obiektami [...] aksjomaty są prawdziwe ze względu na badane obiekty. [...] Strukturaliści odrzucają tę autonomię między aksjomatami a badanymi obiektami. Ponieważ w tradycyjnym platonizmie aksjomaty są stwierdzeniami na temat jakiegoś królestwa idealnych obiektów matematycznych, stąd też możliwe jest, że aksjomaty są fałszywe.

[...] W naszym podejściu język opisuje lub determinuje strukturę (lub klasę struktur), jeśli w ogóle opisuje cokolwiek. (SHAPIro 1997, 131)

Shapiro wyraźnie stwierdza, że w jego koncepcji ostatecznym wyznacznikiem wszystkich własności danej struktury jest jej opis, czyli podanie aksjomatów i ewentualnie reguł wnioskowania. To, czy dane struktury istnieją lub nie, oraz ewentualnie, jak istnieją, jest sprawą otwartą, $\mathrm{W}$ tym kontekście koncepcje współczesnych strukturalistów wydają się nie być wystarczająco precyzyjne. Można znaleźć fragmenty, w których np. Shapiro opisuje swoje poglądy dotyczące ontologicznego statusu struktur matematycznych, wyraźnie odróżniając te struktury od badanych aksjomatycznych teorii matematycznych. Sądzimy, że możliwa jest taka wizja strukturalizmu, w którym struktura i teoria będą tym samym. Właśnie tak proponujemy rozumieć stanowisko strukturalistyczne, nie wdając się w wciąż trwające spory odnośnie do ontologicznego statusu ewentualnych struktur matematycznych. Można jedynie zauważyć, że nieustalony status ontologiczny struktur matematycznych przy jednoczesnej zgodzie na temat tego, że struktury są przedmiotem badań matematycznych, może być pewnego rodzaju wsparciem za prezentowaną odmianą strukturalizmu.

Oczywiście, o czym już wspomniano, można mieć wątpliwości, czy faktycznie jest tak, że matematyka jest pewną teorią czysto formalną, teorią znajdującą się w trzecim aksjomatycznym abstrakcyjnym stadium. Chociaż celem tego artykułu nie jest odpowiedź na to pytania, to wskażemy kilka punktów, które mogą być pomocne w znalezieniu na nie odpowiedzi.

Zauważmy, że autorzy, klasyczni, jeżeli chodzi o podstawy matematyki, dostrzegają możliwość takiego uprawiania matematyki, przy którym jej aksjomatów nie będzie traktowało się jako prawdziwe lub fałszywe, ale jedynie jako pewną grę symboli, którym można nadawać dowolne interpretacje. Wspomniany już Bertrand Russell wyraźnie pisze, że „taki sposób postępowania nie jest błędny, a pod pewnymi względami nawet jest to uogólnienie wartościowe” (Russell 1920, 27), Podobnie uważał Alfred Tarski, który ustosunkował się do możliwości uprawiania matematyki jako nauki czysto dedukcyjnej: 
Zdarza się, co prawda, że budując pewną teorię dedukcyjną, nie przypisujemy jej terminom określonego znaczenia i odnosimy się do nich jak do symboli zmiennych. W takich okolicznościach mówimy, że traktujemy teorię jako system formalny. Ale sytuacja tego rodzaju [...] zdarza się tylko, gdy dysponujemy kilkoma modelami czy interpretacjami dla systemu aksjomatycznego tej nauki, a więc jeśli mamy szereg możliwości przypisania konkretnego znaczenia terminom występującym w tej nauce, ale żadnej z tych możliwości nie chcemy wyróżniać. Taki natomiast system formalny, dla którego nie potrafilibyśmy podać ani jednego modelu, przypuszczalnie nikogo by nie interesował. (TARSKI 2012, 135)

Tarski okazuje się być sceptyczny co do możliwości uprawiania matematyki jako nauki czysto dedukcyjnej, znajdującej się w aksjomatycznym abstrakcyjnym stadium rozwoju. Według niego traktowanie teorii dedukcyjnej jako niezinterpretowanej, w której nie przypisuje się żadnego znaczenia terminom wykorzystywanym w aksjomatach, jest możliwe, ale mało interesujące i niewarte większej uwagi. Podobnego zdania jest Russell, który — jak powiedziano - dostrzega możliwość uprawiania matematyki w omawiany sposób, ale twierdzi, że jest to błędne podejście:

Lecz z dwóch punktów widzenia nie daje on [sposób traktowania matematyki jako nauki czysto dedukcyjnej - M.Cz.] odpowiedniej podstawy dla arytmetyki. Po pierwsze, nie pozwala nam stwierdzić, czy są jakiekolwiek zbiory rzeczy, które spełniają aksjomaty Peana, i nie daje najmniejszej sugestii, jak odkryć, czy istnieją takie zbiory. Po wtóre, jak to już zauważyliśmy, chcemy, by nasze liczby były takie, jakich potrzeba, by liczyć przedmioty życia codziennego, a to wymaga, by nasze liczby miały znaczenie określone, nie zaś tylko, by miały pewne własności formalne. To określone znaczenie definiuje logiczna teoria arytmetyki. (RusSELL 1920, 27).

W związku z tym, można twierdzić, że istnieje pewna granica pomiędzy matematyką jako nauką, znajdującą się w drugim aksjomatycznym intuicyjnym stadium rozwoju, a matematyką jako nauką czysto dedukcyjną (strukturalną), czyli znajdującą się na trzecim aksjomatycznym abstrakcyjnym etapie. Granicę tę może wyznaczyć odpowiedź na pytanie dotyczące prawdziwości aksjomatów oraz powiązane z tym zagadnienie istnienia struktur jako obiektów odrębnych od teorii dedukcyjnych i opisywanych przez nie. Dla teorii znajdujących się w stadium drugim aksjomatycznym intuicyjnym zasadne jest pytanie o prawdziwość aksjomatów w relacji do istniejących obiektów (struktur). Proponowane aksjomaty mogą być w tym przypadku prawdziwe lub fałszywe, natura i sposób istnienia struktur może być taki lub inny. Natomiast dla teorii znajdujących się w stadium trzecim 
aksjomatycznym abstrakcyjnym pytanie o prawdziwość aksjomatów jest nieuzasadnione, nie mówi się o żadnej relacji między teorią dedukcyjną a dowolnie rozumianymi obiektami (strukturami), aksjomaty nie są ani prawdziwe ani fałszywe, znaczenie użytych w nich terminów jest nieustalone.

Protagonista koncepcji trójetapowego rozwoju nauk formalnych, Kazimierz Ajdukiewicz, twierdzi, że o tyle można mówić o prawdziwości aksjomatów, o ile w ogóle istnieją przedmioty, które spełniają dane układy aksjomatów.

Jest rzeczą jasną, że aksjomaty abstrakcyjnej teorii dedukcyjnej, która posiada choć jeden model, muszą być prawdziwe przy tym znaczeniu jej swoistych terminów pierwotnych, które konstytuujemy, postanawiając, że mają posiadać takie denotacje, dla których aksjomaty są spełnione. Albowiem język teorii abstrakcyjnej sami dopiero budujemy, przyporządkowując jego terminom ich denotację. W języku tym terminy denotują więc takie przedmioty, jakie postanowiliśmy im przyporządkować jako ich denotacje [...]

Skoro więc postanowiliśmy, że mają one denotować takie przedmioty, które spełniają aksjomaty, to - o ile takie przedmioty w ogóle istnieją — terminy te denotują też w języku przez nas utworzonym takie przedmioty, które spełniają aksjomaty, a tym samym w języku tym nasze aksjomaty są prawdziwe. (AsduKIEWICZ 1965, 190-191)

Widać wyraźnie, że uznanie matematyki za naukę o strukturach w proponowanym, czysto formalnym sensie, jako pewnej aksjomatyczno-abstrakcyjnej teorii dedukcyjnej, sprawia, że podstawowe pytania dotyczące natury struktur matematycznych oraz sposobu ich poznania schodzą na plan dalszy. Być może jest to pewna wskazówka, która rzuca jakieś światło na zagadnienie różnorodności poglądów dotyczących metafizycznej natury struktur matematycznych, która jest obecna u wielu współczesnych autorów reprezentujących ten nurt filozofii matematyki.

Dyskutując zagadnienie prawdziwości aksjomatów, a co za tym idzie sposobu istnienia struktur matematycznych, w opozycji do czysto dedukcyjnego rozumienia teorii matematycznych należy pamiętać również o znanym ograniczeniu dla takich teorii. Kurt Gödel udowodnił, że dla każdej sformalizowanej, niesprzecznej i bogatej teorii dedukcyjnej zbiór zdań dowodliwych nie pokrywa się ze zbiorem zdań prawdziwych, w tym sensie, że o wszystkich zdaniach dowodliwych zakładamy, że są prawdziwe, natomiast istnieją pewne zdania, będące poprawnie zbudowanymi wyrażeniami tej teorii, które są prawdziwe, a które nie mogą być udowodnione na podstawie przyjętych reguł i aksjomatów. Co więcej, dołączenie zdań prawdziwych do zbioru aksjomatów, w pewien sposób automatycznie powoduje pojawienie się kolejnych takich zdań, które są prawdziwe i jednocześnie niedowodliwe. 
Dowód jest wciąż jedyną metodą używaną do ustalania prawdziwości zdań w obrębie każdej poszczególnej teorii matematycznej. Zdajemy sobie jednak obecnie sprawę, że istnieją zdania sformułowane w języku danej teorii, które są prawdziwe, lecz nie są dowodliwe, i musimy się liczyć z możliwością, że takie właśnie zdania znajdują się wśród tych, którymi się interesujemy i które usiłujemy udowodnić. (TARSKI 1969, 332)

Zdania, które wydają się być prawdziwe, a których nie udało nam się udowodnić w pewnej teorii dedukcyjnej, można dołączyć do zbioru aksjomatów jako nowe założenia, tworząc nową abstrakcyjną teorię dedukcyjną, $\mathrm{W}$ ten sposób prawda może być potraktowana jako pewnego rodzaju drogowskaz, który pozwala rozszerzać abstrakcyjne teorie dedukcyjne.

W rozwoju matematyki nie ma konfliktu między pojęciem prawdy i pojęciem dowodu; pojęcia te nie są na stopie wojennej, lecz pozostają w stanie pokojowego wspólistnienia. (TARSKI 1969, 332)

Rozdźwięk między czysto dedukcyjnymi, abstrakcyjnymi teoriami a teoriami w stadium intuicyjnym, gdzie rozważa się prawdziwość postulatów, może stanowić pewną inspirację dla prób odpowiedzi na pytanie, czy matematyka jest nauką o strukturach. Przy jednym z tych sposobów rozumienia matematyki zasadne są pewne pytania, a przy drugim stawiamy inne pytania i oczekujemy innych odpowiedzi.

[...] istnieją dwa wzajemnie nieredukowalne sposoby rozumienia metody matematycznej: jeden skupiony na prawdzie a drugi na wynikaniu. W stadium intuicyjnym można zadawać takie pytania jak «Ile istnieje linii prostych równoległych do danej prostej?».

W stadium abstrakcyjnym można zadawać takie pytania jak «Co wynika $\mathrm{z}$ teorii Riemanna lub Euklidesa?» (ТкасZук 2016, 37)

Podsumowując, możliwa jest taka interpretacja strukturalizmu matematycznego, że strukturalność i dedukcyjność matematyki stają się cechami zamiennymi. Natomiast pytanie o to, czy matematyka jest nauką właśnie tak rozumianą, czyli znajdującą się w stadium abstrakcyjnym, uważamy za otwarte i wielce dyskusyjne. 


\section{REFERENCJE}

Ajdukiewicz, Kazimierz. 1921. „Pojęcie dowodu w znaczeniu logicznym”. W: Język i poznanie. T. 1. Warszawa: Państwowe Wydawnictwo Naukowe [PWN] (= AJdukiewicz 1960).

AjDukiewicz, Kazimierz. 1960. Język i poznanie. T, 1. Warszawa: Państwowe Wydawnictwo Naukowe [PWN].

Ajdukiewicz, Kazimierz. 1965. Logika pragmatyczna. Warszawa: Państwowe Wydawnictwo Naukowe [PWN].

Benacerraf, Paul. 1965. „What Numbers Could Not Be”. Philosophical Review 74: 47-73. Przedruk w: Benacerraf i Putnam 1983, 271-294.

Benacerraf, Paul, i Hilary Putnam H. 1983. Philosophy of mathematics. selected readings, Cambridge: Cambridge Universitv Press.

CAnToR, Georg (1883), Grundlagen einer allgemeinen Mannigfaltigkeitslehre. Leipzig: Teubner. Przedruk w: ZeRMELO 1932.

DADACZYŃSKI, Jerzy. 2002a. „Antynomie teoriomnogościowe a powstanie klasycznych kierunków badania podstaw matematyki”. W: Matematyka w oczach filozofa, 224-243. Kraków: OBI, Tarnów: Biblos (= DADACZYŃSKI 2002b).

DADACZyŃSKI, Jerzy. 2002b. Matematyka w oczach filozofa. Kraków: OBI, Tarnów: Biblos,

DEDEKIND, Richard. 1888. Was sind und was sollen die Zahlen?. Brunsehweig: Fredrieh Yieweg und Solin. Ang.: The nature and meaning of numbers. Tłum. Wooster Woodruff Beman. W: DeDEKIND 1963, 1-58.

Dedekind, Richard. 1963. Essays on the Theory of Numbers. Tłum. Wooster Woodruff Beman. New York: Dover Publications,

Heiberg, J.L., i Richard FitzPatrick. 2008. Euclid's Elements of geometry: the Greek text of J.L. Heiberg (1883-1885): from Euclidis Elementa edidit et Latine interpretatus est I.L. Heiberg, in aedibus B.G. Teubneri, 1883-1885. Edited, and provided with a modern English translation, by Richard Fitzpatrick. First edition - 2007. Revised and corrected 2008. B.m.w.: b.w.

Hellman, Geoffrey. 1989. Mathematics without Numbers: Towards a Modal-Structural Interpretation. Oxford: Clarendon Press.

Hellman, Geoffrey. 2001. „Three Varieties of Mathematical Structuralism”. Philosophia Mathematica 9, issue 2: 184-211. DOI: 10.1093/philmat/9.2.184.

Hellman, Geoffrey. 2005. „Structuralism”. W: The Oxford Handbook of philosophy of mathematics and logic, red. Stewart Shapiro, 536-562. Oxford: Oxford University Press (= SHAPIRO 2005),

Horsten, Leon. 2007, Philosophy of Mathematics. W: The Stanford Encyklopedia of Philosophy (Spring 2019 Edition), red. Edward N. Zalta. Dostęp 2.01.2019. https://plato.stanford.edu/ entries/philosophy-mathematics.

Murawski, Roman. 1994. Filozofia Matematyki. Antologia tekstów klasycznych, Poznań: Wydawnictwo Naukowe UAM.

Mostowski, Andrzej. 1967. „O niektórych nowych wynikach meta-matematycznych dotyczących teorii mnogości”. Studia Logica 20: 99-116.

Parsons, Charles 1990. „The Structuralist View of Mathematical Object”. Synthese 84, no, 3: The Philosophy of Mathematics, Part II (Sep. 1990): 303-346. 
RECK, Erich H. 2003. „Dedekind's Structuralism: An Interpretation and Partial Defense”. Synthese 137, no. 3: 369-419.

RESNIK, Michael D. 1981. „Mathematics as a Science of Patterns: Ontology and Reference”. Nous 15, no, 4: Special Issue on Philosophy of Mathematics (Nov., 1981): 529-550.

Resnik, Michael D. 1996. „Structural Relativity”. Philosophia Mathematica 4, issue 2: 83-99.

RESNIK, Michael D. 1997. Mathematics as a Science of Patterns. Oxford: Clarendon Press.

Russell, Bertrand. 1920. Introduction to Mathematical Philosophy. London: George Allen and Unwin, LTD. Tłum, pol. Wstęp do filozofii matematyki. Tłum, Czesław Znamierowski, Warszawa: Fundacja Aletheia, 2003.

SHAPIRo, Stewart (ed.). 2005. The Oxford Handbook of philosophy of mathematics and logic, Oxford: Oxford University Press,

Shapiro, Stewart. 1997. Philosophy of Mathematics: Structure and Ontology. Oxford: Oxford University Press.

TARski, Alfred. 1969. „Truth and Proof”. Scientific America 220, no. 6: 63-77. Pol.: „Prawda i dowód”. Tłum. Jerzy Krzywicki, w: TARSKI 1995, 292-332.

TARski, Alfred. 1995. Pisma logiczno-filozoficzne. T. 1: Prawda, red. Jan Zygmunt, Warszawa: Wydawnictwo Naukowe PWN.

TARSKI, Alfred. 2012. Wprowadzenie do logiki i metodologii nauk dedukcyjnych, Warszawa: Fundacja na rzecz informatyki, logiki i matematyki.

Tкасұук, Marcin. 2016. „Kazimierz Ajdukiewicz's Philosophy of Mathematics, Studies in East European Thought 68: 21-38. DOI: https://doi.org/10.1007/s11212-016-9245-x.

Torretti, Ricardo. 1999. The Philosophy of physics. Cambridge: Cambridge University Press,

Van Heijenoort, Jean. 1967. From Frege to Gödel. A Source Book in Mathematical Logic, 18791931. Harvard: Harvard University Press,

Von Neumann, Johann. 1923. „Zur Einfuhrung der transfiniten Zahlen”. Acta litteraria Academiae Scientiarum Szegedensis. Acta Scientiarum Mathematicarum 1: 199-208.

Zermelo, Ernst. 1908, „Untersuchungen über die Grundlagen der Mengenlehre. I”. Mathematische Annalen 65, Nr 2: 261-281. DOI: https://doi.org/10.1007/BF01449999. Ang.: „Investigation in the Foundations of Set Theory. I”. w: van HeIJEnoort, 1967, ???-???.

Zermelo, ERnst (red.). 1932. Georg Cantor, Gesammelte Abhandlungen mathematischen und philosophischen Inhalts. Berlin: Verlag von Julius Springer.

\section{STRUKTURALNOŚĆ A DEDUKCYJNOŚĆ MATEMATYKI. WSPÓECZESNY STRUKTURALIZM \\ W FILOZOFII MATEMATYKI}

Streszczenie

Wspólne dla różnego typu strukturalizmów matematycznych jest stwierdzenie, że dla matematyki jako nauki prawdziwa jest koniunkcja: a) matematyka jest nauką o strukturach oraz b) matematyka jest nauką dedukcyjną.

Przedstawiane są odmienne argumenty na rzecz tych dwóch własności matematyki i różnie rozumiane są pojęcia strukturalności i dedukcyjności, co skutkuje powstawaniem różnego rodzaju strukturalizmów. Twierdzimy, że przy pewnym ustalonym sposobie rozumienia tych pojęć możliwa jest ich równoważność. Argumentujemy na rzecz takiego rozumienia strukturalizmu, 
które streszcza się w stwierdzeniu: a) matematyka jest nauką o strukturach wtedy i tylko wtedy, gdy b) matematyka jest nauką dedukcyjną.

Słowa kluczowe: filozofia matematyki; strukturalizm matematyczny; struktura; dedukcja; strukturalność matematyki; dedukcyjność matematyki; strukturalizm sui generis; teoria mnogości; metodologia matematyki.

\section{STRUCTURALITY AND DEDUCTIVITY OF MATHEMATICS: CONTEMPORARY STRUCTURALISM IN THE PHILOSOPHY OF MATHEMATICS}

\section{Su m m a ry}

It is common for different types of mathematical structuralism that the conjunction of two statements ( a) mathematics is science about structures and b) mathematics is deductive science) is true, Distinct arguments for this two features of mathematics are exanimated therefore the main concepts (structurality and deductivity) are understood differently, the results are various types of structuralism. We claim that it is possible to establish the way of understood of this two concepts in witeh they are equivalent. We argue that can interpret mathematical structuralism as equivalence: a) mathematics is science about structures if and only, if b) mathematics is deductive science

Keywords: philosophy of mathematics; mathematical structuralism; structure; deduction; structurality of mathematics; deductivity of mathematics; structuralism sui generis; set theory; methodology of mathematics.

Information about Author: Marcin CZaKon, PhD - the John Paul II Catholic University of Lublin, Faculty of Philosophy, Institute of Philosophy, Department of Logic; address for correspondence: Al. Racławickie 14, 20-950 Lublin; e-mail: marcin.czakon@kul.pl; ORCID: https://orcid.org/0000-0001-6217-6640. 